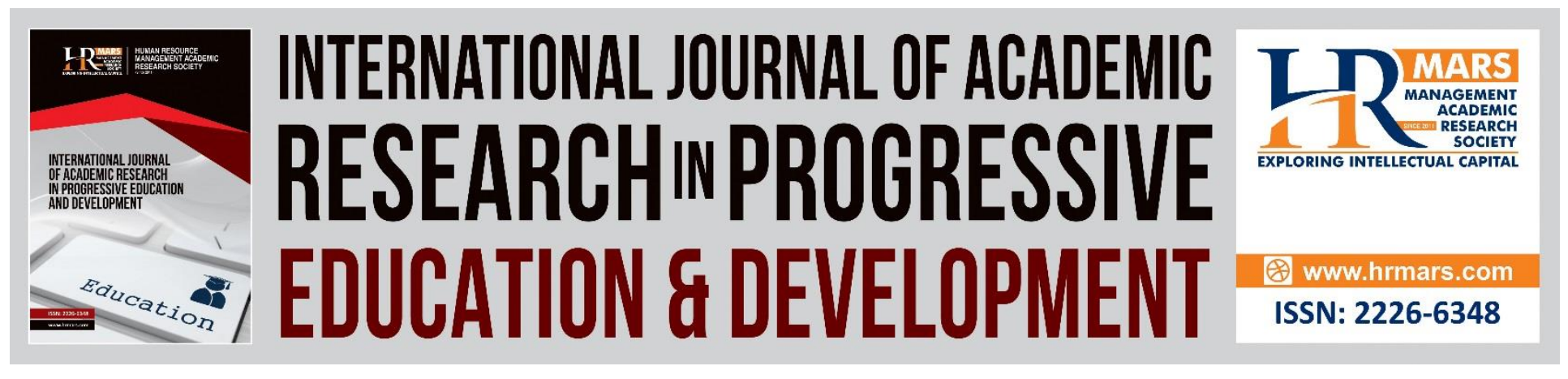

\title{
English Vocabulary Development Among Undergraduates: Social Media
}

\author{
Nalini arumugam, Nurainatul Farhanahburhanuddin, Puspalata C Suppiah, \\ Mohamad Idham Md Razak
}

To Link this Article: http://dx.doi.org/10.6007/IJARPED/v9-i4/8455

DOI:10.6007/IJARPED/v9-i4/8455

Received: 05 October 2020, Revised: 07 November 2020, Accepted: 20 December 2020

Published Online: 31 December 2020

In-Text Citation: (Arumugam et al., 2020)

To Cite this Article: Arumugam, N., Farhanahburhanuddin, N., Suppiah, P. C., \& Razak, M. I. M. (2020). English Vocabulary Development Among Undergraduates: Social Media. International Journal of Academic Research in Progressive Education and Development, 9(4), 128-146.

Copyright: (C) 2020 The Author(s)

Published by Human Resource Management Academic Research Society (www.hrmars.com)

This article is published under the Creative Commons Attribution (CC BY 4.0) license. Anyone may reproduce, distribute, translate and create derivative works of this article (for both commercial and non-commercial purposes), subject to full attribution to the original publication and authors. The full terms of this license may be seen at: http://creativecommons.org/licences/by/4.0/legalcode

Vol. 9(4) 2020, Pg. 128 - 146

http://hrmars.com/index.php/pages/detail/IJARPED

JOURNAL HOMEPAGE

Full Terms \& Conditions of access and use can be found at http://hrmars.com/index.php/pages/detail/publication-ethics 


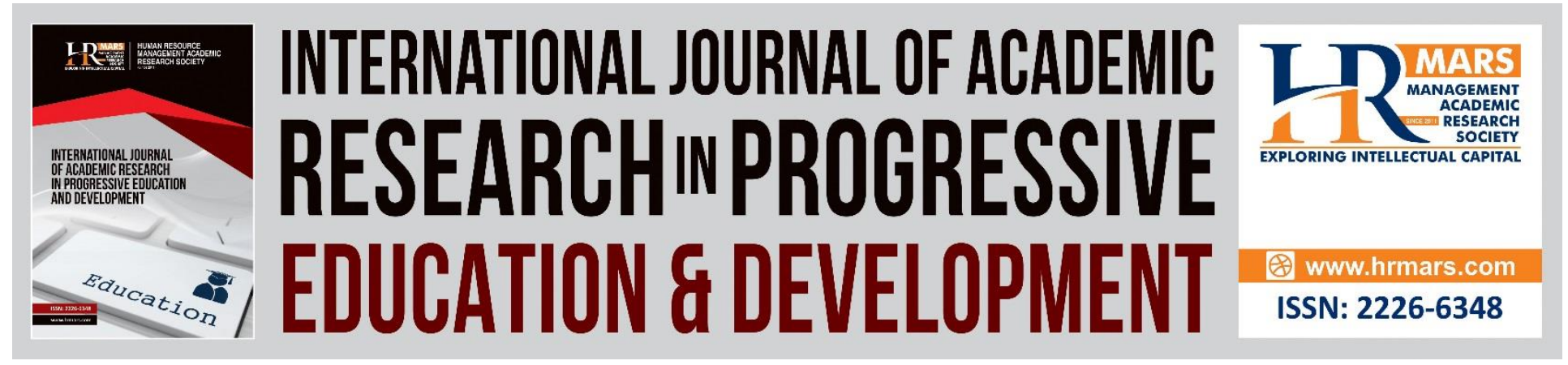

\title{
English Vocabulary Development Among Undergraduates: Social Media
}

\author{
Nalini Arumugam ${ }^{1}$, Nurainatul Farhanahburhanuddin ${ }^{2}$, \\ Puspalata C Suppiah ${ }^{3}$, Mohamad Idham Md Razak ${ }^{4}$ \\ ${ }^{1,3}$ Akademi Pengajian Bahasa, Universiti Teknologi MARA, 40150 Shah Alam, Selangor Darul \\ Ehsan, Malaysia, ${ }^{4}$ Faculty of Business and Management, Universiti Teknologi MARA \\ Cawangan Melaka, 77300 Kampus Jasin, Melaka, Malaysia
}

\begin{abstract}
Social networks play a crucial role in fostering second language learning by providing a wide array of resources and facilitate global interaction among youngsters today. Language instructors therefore should consider using these tools into their learning platform to enrich students' language learning experience. Due to the increased popularity of virtual learning platforms, this study aims to inspect the perceptions of university students about the use and roles of social media in learning English vocabulary. The primary method used for this research study is a quantitative research approach which involves a total of 193 undergraduates from different faculties in University Teknologi MARA (UiTM). The data is gathered through questionnaire and analysed by applying descriptive statistical tools. The eventual findings indicated that undergraduates benefited from the numerous functions of social media in learning and developing English vocabulary. They also said that social media can be used as a apt platform by instructors to communicate with students on course-related material and enable them to share educational information in text, images and videos. It is therefore recommended that educators adapt Gen Z's learning preference via interactive social media tools in the learning of vocabulary. Keywords: Social Media, Learning Preference, Vocabulary, Virtual Learning, Knowledge
\end{abstract}

\section{Introduction}

Vocabulary learning is a process of acquiring new words in second language acquisition. It is more than just understanding what the word means but is the basic factor necessary for mastering a language effectively. Alqahtani (2015) and Khan (2016) mentioned that vocabulary knowledge is regarded as an important instrument for second language students as inadequate vocabulary knowledge in a second language delays successful communication. In any language, mastering vocabulary is a significant phase to expedite learners' successful communication in the language $(\mathrm{Gu}, 2003)$. Schmitt (2000, p. 55) emphasises that "lexical knowledge is central to communicative competence and to the acquisition of a second language". Moreover, researchers like Tozcu and Coady (2004), and Nation (2011) did not dispute the fact that enriching vocabulary is crucial for 
efficacious second language use as well as empowering one's spoken and written communication. Lack of extensive vocabulary also deters the learners from using proper structures and functions needed for coherent communication (Rivers, 1981; Nunan, 1991). Wilkins (1972, p. 97) agrees that "There is not much value in being able to produce grammatical sentences if one has not got the vocabulary that is needed to convey what one wishes to say ... While without grammar very little can be conveyed, without vocabulary nothing can be conveyed". These suggest that developing lexical and communicative ability in English is fundamental to accelerate learners in recognising relevant 'linguistic features' and 'translinguistic structures' in their communication (Viera, 2016).

With the world of internet and social media nowadays, students can learn language through social networking. A survey conducted by Malerba, (2011), found most of the hours consumed online were spent in social networking sites. The internet plays an enormous role in creating a prominent linguistic context and environment through its interactive two-way communication (Faizi, El Afia \& Chiheb, 2013; Dhanya, 2016). For example, social media specifically Facebook, Blogs and Twitter can help students meeting other language learners. It is a great platform to share content and promote discussion with people all around the world. Certainly, social media learning approach can enhance both social and interactive method to language learners. According to Duff (2002), socialisation empowers the language "novices" to study and acquire from those who are "experienced" especially in speech communities. Arumugam, Ismail, Selvanayagam, and Sathiyasenan (2019) advocated that social media platforms have much potential among the undergraduates in learning the English language and their use of the online platform as a pedagogical method enriches students' learning outcomes. In this digital era people use the social media for numerous tenacities. Particularly in the field of education, the worldwide technology and Internet revolution have changed the students' learning styles, the list of well-known styles such as open learning, distance learning, e-learning and social media learning (Churchill, Wong, Law, Salter, \& Tai, 2009). Mutum and Wang (2010) claimed that English Language learners can easily use online resources to heighten their mastery in the language. For example, online blogs and social media platforms facilitate their users to send messages or give comments regarding different issues which in turn augment their mastery in the language. Young adults who often use innovative technologies to create instant communities of practice predominantly sites like Facebook and MySpace social networking sites have attained increasing fame (Castells, 2007). Grosseck, Bran and Tiru (2011) opined that Facebook and other social networking sites can become a reliable source of reference for academic purposes primarily in the higher educational settings.

The rise of the use of Internet has permitted learning to escape from the boundaries of usual classroom environment. In language teaching and learning, social media present an ocean of information for improving language vocabulary (Mohammed, Al-Khazaalia, \& Al-Kadhum, (2019). Alqahtani (2015) agrees that the vocabulary element has a significant role in second language learning and thus, inadequate vocabulary knowledge delays successful communication. Additionally, researchers (Gu, 2003; Marion, 2008; Nation, 2011) signposted that the mastery of 
vocabulary is crucial for effective second language use as vocabulary enhances one's spoken and written communication.

\section{The role of Social Media}

Social media is a technology that enables the sharing of ideas and information which creates virtual communication around the world (Hashim, Rashid, \& Atalla, 2018). ). Hua Wang, Weiai, Gregory, and Singhal (2019) claimed that social media fandom has the potential to meaningfully facilitate learning even an online teen drama which expanded its story world through a wide range of digital platforms. In Nigeria, media was used to capture the youths to develop civic minded citizenship (Mustapha \& Atoloye, 2019). This is an opportune reminder for educators to bring social media as a frequent device in classrooms.

Annamalai (2018) stated that learners are optimistic in using social media as an online environment for learning. Social media such as Facebook, WhatsApp, and Email offer platforms that allowed interactions, collaborations and instant feedback at any time and any place. Every social media platform will alert their users about certain information and users can choose what they want to appear in their notifications (Yu, Tian, Vogel, \& Kwok, 2010). Hebblethwaite (2017) reported that an average person has 7.6 active social media accounts, with $98 \%$ of people at least one social media account. The Social Network is one of the most important keys for the Internet which connects people from all over the world. This huge connection has benefited a lot of people in doing good things (Kay, Kai, \& Jun, 2014). Though Facebook is the most commonly used social networking platform, there are many other social media platforms that assist people in different features such as Twitter, YouTube, Instagram and many more.

In short, students use social media to keep their mental health intact. Social media not only assists students to improve their proficiency in the English language but also expands their circle of friends and enhances their knowledge besides information (Badri et. al, 2017). There are about 100 social media platforms in existence and over a billion registered users on these sites, hence, social media today has become a way of life.

\section{Twitter}

Twitter can be used for a user to send short 140-words messages called "tweets". Twitter users can read and post tweets and other users and retweets them. From twitter, the user can create learning hashtags which can help other learners to read the tweet and able to give feedback and communicate (Martin, 2014). Martin further explained that as Twitter has a limit to 140-words characters, it required students to think smartly and critically as they have to point their main idea. Twitter's main aims are; instantaneous communication and content sharing (Chawinga, 2017). Most of the students agreed that via twitter, they have experienced interactive and independent learning and instant communication. This learning platform has given an opportunity for students to express themselves freely. 


\section{Facebook (FB)}

FB is a user-friendly application used by many as a tool for social networking. Mahmud and Ching (2012) said that FB seems to play a role in learning the English language among students. Most of the students concurred that FB assists them in boosting their confidence and self-esteem when communicating in English. Nations (2019) too concurs to this perspective. FB too can be a good resource for the educators to share materials or host a discussion. Besides, it promotes associations and rapport between teachers and students correspondingly. Abrahim, Mir, and Sato (2018) stated that Facebook with user-friendly features has brought an incredible transformation in the information and communications progress. Ahmed, (2016) indicated in his study that FB enhanced students' academic performance and students experienced more meaningful learning environment using FB features. Khan, Ayaz, and lara, (2016) shared that educators too perceive FB to be an interactive social media platform for students master the second language skills especially learning new vocabularies when observing their friends posts and comments.

\section{YouTube}

YouTube is one of the most popular websites and it is a massive resource for educational content. Bevan (2017) and Dhanya (2016) indicated that YouYube platform is visual and entertaining which fascinates students to watch the video and keep them intact. Using YouTube, educators can create engaging lessons. Videos with lots of visuals can help to stimulate and attract the student's attention because some students learn better by watching rather than reading. In YouTube also creates opportunity for students to watch, save and share the videos. This indirectly creates autonomy learning style.

\section{Telegram}

Telegram is known as another popular instant messaging (IM) services for secure communications. Telegram comprises three types of communication mainly; user to user, onemany (known as a channel in Telegram) and many-many (known as a group in Telegram). Each blog post also benefits from the media-rich enhancements of the new Instant View feature when shared on Telegram (Nobari, Reshadatmand, \& Neshati, 2017). The link can be shared across social media or via Telegram Messenger itself. Clicking the link opens the post in a page native to Telegram, with other websites, including Medium, also supporting Instant View pages.

\section{Tumblr}

Tumblr is a blogging network which assists users to blog in a useful, regardless of content form; text, audio or video material. This allows users to quickly upload their messages and to share with other users in a community is the key to Tumblr's growing success (Oliver, Dame-Griff, Capello \& Richter, 2019). This makes Tumblr a rich microblogging platforms consisting with hybrid characteristics of social networking, traditional blogosphere, and social media. Through Tumblr, users tend to become more expressive and creative in using a variety of vocabularies which helps them to develop confidence as they construct the vocabulary items (Amichai-Hamburger, 2013). 


\section{Skype}

Skype is a voice-over-internet service which is used to encourage students to communicate with their teachers and friends. The teacher can create an educational group and invite the students to join the discussion. Teachers could use these platforms in order to encourage students or learners to learn or improve their English Language skills in reading and writing, formally and informally (Alsamadani, 2018). A study conducted by García, Diaz, and Artunduaga (2018) revealed that students who used Skype as a means of communication found it useful as it helped them to expand their vocabulary. Correspondingly, Wu, Marek, and Huang (2012, p. 12) said that Skype sessions, "students increased motivation, thought critically about the subjects discussed in class and improve their fluency, pronunciation, grammar, vocabulary and content knowledge".

\section{Social Media and Language Learning}

Social media is beneficial medium of communication to share knowledge can reach almost everyone in the world and it also enables the users to share the knowledge with others (Pavlik et al, 2015). Social media is a significant medium in learning the English Language as it provides an opportunity to the learners to acquire and progress their reading, listening, writing, and speaking.Language instructors can use social media as an educational tool by creating a lot of language games and quizzes to monitor students' learning. Besides that, social media too offers a platform to enhance their learning experiences by providing a chance to disseminate their knowledge and share their information (O' Keefee, 2011).

Faizi et al (2013) advocated that there are lots of potential benefits of using social media in education. It is crucial to the students to discover the probable benefits that social media can offer to the modern education. Social media can also help to improve communication not only among students but also with educators. Students can use the features in social media to talk to each other on assignments or test, sharing educational contents and increase interactivity among students. In fact, Kitchakarn (2016) highlighted that students are comfortable using social media as their learning platform. They found social media convenient to communicate with other users and the functions itself made the learning environment more meaningful despite the negative effects that social network sites have on students' learning as proclaimed by Abdulahi, Samadi, and Gharleghi (2014) in their study. Thus, it is a pertinent reminder for educators to be aware of technological developments and maximise learners' potential skills to facilitate English language skills, especially vocabulary development (Khan, Ayaz \& lara, 2016).

\section{Problem Statement}

The most significant learning element is the teaching approach adopted by the instructors in their classes to expedite language learning (Ahmadi, 2017). Since social media function as an important instructional tool and can now be accessed from tablets, mobile phones and all portable devices to users of any age around the world, it creates a bigger opportunity for language learners to learn and improve their languages. Social media can be used as a platform to learn with a flexible environment to communicate and share information. Although some researchers (Abdulahi, Samadi, \& Gharleghi, 2014; Alnjadat, Hmaidi, Samha, Hijazi \& Hasswan, 2019; Akram \& Albalawi, 2016; Selwyn, 2012) have claimed that the social media have created more harm than 
benefits to university students, Lin, Warschauer, and Blake (2016) and Balakrishnan and Lay (2016) maintained that social media create new horizons especially to the youngsters. Besides, Hafedh (2019) agreed that the students' attitudes towards FB-assisted teaching have shown positive results. Similarly, Khan, Ayaz and lara (2016) advocated that social media expedites the English learners to learn new words, phrases and improve their vocabulary. This is because, the features on social media attract the curiosity of ESL learners to learn English language. In another study, Annamalai (2018), revealed that students have shown constructive attitudes about the use of the online environment for learning activities particularly in encouraging them to become independent learners. Additionally, Mahmud and Ching (2012) shared from their research that social media promote language learning among undergraduates. While most studies have focused on students with diverse cultural backgrounds, little has been done on how social media help to develop English language vocabulary among monocultural undergraduates. Amidst the claims and counter claims, the present research aims to investigate the perceptions of undergraduates towards the use of social media in English vocabulary development and to identify the purposes of social media in learning English language vocabulary at the university level. To fill the gap, this study aims to answer the following research questions.

1. What are the perceptions of university students about the use of social media in English Language vocabulary development at the university level?

2. What is the function of social media in learning English vocabulary at the university level?

\section{Significance of Study}

In this $21^{\text {st }}$ century, the outcome of this study could be useful for the students, educators and social media users. Besides that, it will also give students a view that social media do not only serve as an entertainment platform but it can be utilised for academic gains. This study also facilitates the educators to consider social media as the main platform in teaching and it may change the educators' view towards the usage of social media. The results of this research also inspire the social media users to recognise and understand the use of social media as a learning platform.

\section{Conceptual Framework}

This research used the theoretical model of the Technology Acceptance Model (TAM) by Davis (1989). Technology Acceptance Model is one of the most known research models to assume the use and acceptance of individual towards the information and technology systems. This theory undertakes that one's acceptance is determined by two main variables; perceived usefulness (PU) and Perceived Ease of Use (PEOU). Davis (1989) well-defined that usefulness of a specific application enhances one's life, academic or work performance while the user-friendliness makes user comfortable. Conferring to TAM, the ease of use and perceived effectiveness is the most vital factors of real system users. Furthermore, these two factors are influenced by external variables such as political factors, cultural factors, and social factors. However, this study focuses only on social factors. Social factors include language, facilitating, and skills settings. The behavioural intention of the individual is the assess of the probability of a person employing the application. 
Figure 2.1 Technology Acceptance Model (TAM) by Davis (1989)

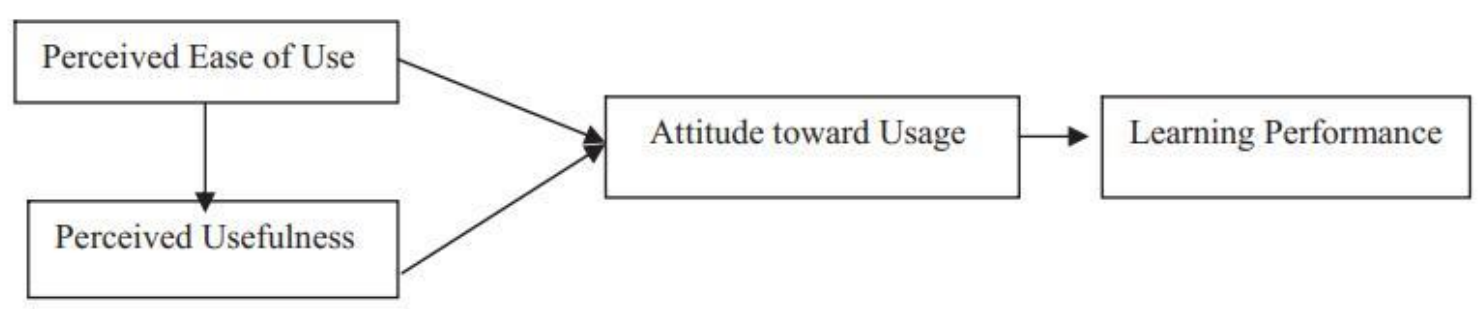

This study used the above conceptual framework to investigate the undergraduates' views toward social media as a medium for learning English vocabulary. This study also focused on the functions of social media use in learning English vocabulary.

\section{Methodology}

The primary research method used in this study is quantitative research. In the quantitative research method, the researchers ensured the accuracy of the information gathered. The sample of data involved 193 undergraduates from different faculties in University Teknologi MARA (UiTM). In gathering the data for this study, a set of questionnaire was adapted from Wang, Jackson, Gaskin and Wang (2014). The questionnaire was distributed only to UiTM students through Google Form. The questionnaire consisted of three parts: Part I of the questionnaire was designed to gather information about students' demographic information includes gender, age, which social media they prefer, average hours they would spend on social media. Part II aimed to gather information about the perceptions of undergraduates on the use of social media in the vocabulary development of English Language. Part III was designed to gather information about general uses and functions of social media in helping the students to learn English Language vocabulary. Both Part II and III were structured in the Likert Scale, on a 4 - point scales, ranging from strongly agree, agree, disagree and strongly disagree. Later the responses were merged into two categories: strongly agree and agree for agree responses, and strongly disagree and disagree for disagree responses. The collected data from the questionnaire were analysed using descriptive analysis.

\section{Social Media Usage among Undergraduates}

The demographic information revealed that undergraduates in UiTM used different types of social media. It was found that WhatsApp (91.4\%) is the most commonly used social media platform among the undergraduates, followed by Twitter (88.2\%), YouTube (58.1\%), Facebook (33.3\%), Skype (8.6\%), Tumblr (3.2\%), and Telegram (1.1\%). WhatsApp is an application used mostly by people to communicate in their daily life. This instant messaging system offers its users the facility to interact and share with their friends instantaneously while Facebook is the largest social networking site in the world founded by Mark Zuckerberg. 
Vol. 9, No. 4, 2020, E-ISSN: $2226-6348$ @ 2020 HRMARS

This instant messaging platform gives its users the ability to communicate and share instantly with individuals and groups while Facebook is the largest social networking site in the world founded by Mark Zuckerberg.

Table 1: The percentage of social media usage between genders

\begin{tabular}{|c|c|c|c|}
\hline Gender & \multicolumn{3}{|c|}{ Usage of Social Media (\%) } \\
\hline & One Hour A Day & 3 Hours A Day & Up To 8 Hours \\
\hline Female & 1.08 & 15.1 & 39.8 \\
\hline Male & 1.08 & 11.8 & 31.2 \\
\hline
\end{tabular}

Table 1 shows that $39.8 \%$ female undergraduates spend up to 8 hours a day using social media followed by $15.1 \%$ spending around 3 hours a day and $1.08 \%$ spending one hour per day. As for the male undergraduates, $31.2 \%$ spend up to 8 hours a day using social media, $11.8 \%$ of them spend around 3 hours a day and $1.08 \%$ spend once a day on social media. Female undergraduates use more social media than male students especially to share personal information. Besides, female undergraduates use social networking sites to create more circle of friends and stay in touch with family or friends while male undergraduates gather the information they need via social media. Additionally, social media assists the students carryout research, collect relevant contacts and eventually upsurge their status (Vermeren, 2015).

Table 2: The relationships between both genders in the frequency of usage of social media in learning vocabulary of English Language

\section{Chi-Square Tests}

\begin{tabular}{|l|c|c|c|}
\hline & Value & Df & $\begin{array}{c}\text { Asymptotic Significance (2- } \\
\text { sided) }\end{array}$ \\
\hline Pearson Chi-Square & $.029^{\mathrm{a}}$ & 2 & .986 \\
\hline Likelihood Ratio & .029 & 2 & .986 \\
\hline $\begin{array}{l}\text { Linear-by-Linear } \\
\text { Association }\end{array}$ & .008 & 1 & .930 \\
\hline N of Valid Cases & 193 & & \\
\hline
\end{tabular}

2 cells (33.3\%) have expected count less than 5. The minimum expected count is .88 .

The Chi-Square Tests result shows that there is no statistically significant relationship between gender and frequency of usage $(x(2)=0.029, p=0.986)$; that indicates gender has no influence on the frequency of usage. This contradicts with the findings of Alnjadat et. al (2019) which stated that there is statistically significant relationship between both gender and the frequency of usage. Their study shows that male students are more addicted to use social media than female undergraduates. Generally, young adults aged between 20 and 24 spend more time on social media because they are afraid that they will miss out any latest news (Omar, 2017; Vermeren, 2015). Furthermore, they feel uneasy if they are unable to check any incoming messages instantly. 
INTERNATIONAL JOURNAL OF ACADEMIC RESEARCH IN PROGRESSIVE EDUCATION AND DEVELOPMENT

Vol. 9, No. 4, 2020, E-ISSN: $2226-6348$ @ 2020 HRMARS

Table 3: The percentage of usage on social networking

\begin{tabular}{|l|c|}
\hline \multicolumn{1}{|c|}{ Items } & Percentage \\
\hline Communicating with friends & $92.5 \%$ \\
\hline Keeping updated with latest news & $90.3 \%$ \\
\hline Sharing information & $79.6 \%$ \\
\hline Communicating with family & $77.4 \%$ \\
\hline Learning through social media & $58.1 \%$ \\
\hline Using social media to complete work & $34.3 \%$ \\
\hline
\end{tabular}

Table 3 shows that respondents use social media for various reasons such as communicating with friends and family, sharing information, learning, working, and to keep abreast of the latest news. Based on the table, it can be said that the main reason for using social media is to communicate with friends (92.5\%) followed by keeping updated with latest news (90.3\%), sharing information (79.6\%), communicating with family (77.4\%), learning (58.1\%) and the lowest chosen item is working (34.3\%). This is in line with Glenn (2013) who stressed that the main functions of social media are to stay connected with people all around the world for free as well as to strengthen relationships.

\section{Perceptions on Learning English through Social Media}

The result indicates that the majority (94.6\%) of the undergraduates think that social media is an appropriate medium for instructors to with students on course-related material. A total of $99 \%$ of the respondents believe that social media is an apt medium for lecturers to interact with undergraduates and vice versa. This shows that many respondents perceive social media as a reliable learning platform that can be used by educators to share any education materials to assist students. Respondents also agreed that social media helps English learners to improve their mastery and confidence in the language. Kitchakarn (2016) too indicated that students felt contented using social media as a learning device in their course as it makes communication with other people easy. He added that students viewed social media as a good place to learn because they can either learn alone or learn together and eventually encourage them to be more interactive and confident.

Furthermore, $96.8 \%$ of the undergraduates agreed that they would recommend their instructors to use social media to teach English and their course-mates to use social media to learn the language especially to share course materials, educational resources, and exam notes. Ahmed, (2016) and Mubarak (2016) shared a similar finding where social media can be a well- 
INTERNATIONAL JOURNAL OF ACADEMIC RESEARCH IN PROGRESSIVE EDUCATION AND DEVELOPMENT

Vol. 9, No. 4, 2020, E-ISSN: $2226-6348$ @ 2020 HRMARS

functioning online learning environment that facilitates English learners. Table 4 illustrates undergraduates' perception of learning the English Language through social media.

Table 4: Undergraduates Perceptions on Social Media Learning Platform

\begin{tabular}{|l|c|c|}
\hline \multicolumn{1}{|c|}{ Items } & $\begin{array}{c}\text { Agree } \\
\%\end{array}$ & $\begin{array}{c}\text { Disagree } \\
\%\end{array}$ \\
\hline $\begin{array}{l}\text { I think social media is a suitable platform to be used by } \\
\text { lecturers to share course-related material with students }\end{array}$ & 94.6 & 5.4 \\
\hline $\begin{array}{l}\text { Social media is useful for second language learners in } \\
\text { sharing communicating with course mates and lecturers }\end{array}$ & 99.0 & 1.0 \\
\hline $\begin{array}{l}\text { I recommend that students and lecturers use social media } \\
\text { as a tool for English sharing materials. }\end{array}$ & 96.8 & 3.2 \\
\hline $\begin{array}{l}\text { Social Media facilitate English learners in the second } \\
\text { language learning process }\end{array}$ & 97.6 & 2.4 \\
\hline $\begin{array}{l}\text { Social media encourages me to be more interactive and } \\
\text { confident in communicating with others in English }\end{array}$ & 94.6 & 5.4 \\
\hline $\begin{array}{l}\text { Itend to use social media or learning website to learn English } \\
\text { Learning English language in a social media environment } \\
\text { creates less anxiety for me }\end{array}$ & 94.6 & 5.4 \\
\hline $\begin{array}{l}\text { Learning English through traditional-based classroom is not } \\
\text { interesting }\end{array}$ & 88.1 & 11.9 \\
\hline
\end{tabular}

$97.6 \%$ of the respondents perceived that social media is useful for second language learners to learn the language, in this case the English language. Besides that, $94.6 \%$ agreed that social media encourages them to be more interactive and confident in communicating with others in English. This finding is consistent with Khan, Ayaz, and Faheem (2016) who stated that social media play a substantial role in students' English language acquisition as it is very useful for them to compare to books and other reading materials because it can attract the interest of English language learners with colourful images or videos posted on social media.

94.6\% of the undergraduates agreed that they are inclined to use social media or learning website to learn English language and secondly because learning the language through social media environment creates less anxiety for them respectively. This finding is similar to Said Ahmed (2016) and Chawinga (2017) who mentioned that students use social media account such as FB as a means for language learning because this is an up-to-date learning platform which is easily accessible and also provides convenience and more options for students to learn English language. Ahmed (2016) and Alqahtani (2015) too stated that social media can be accessed easily, free and attractive to its users. It can be viewed as the new platform for students to express themselves freely. 
88.1\% agreed that learning English vocabulary through traditional-based classroom is not interesting. Although Mubarak (2016) stated that a traditional typical classroom environment is still the most necessary medium for English language learning, the results of this study revealed that language learners generally enjoy using social media as an additional learning instrument to learn English which shares the school of thought with Annamalai, (2018).

In short, undergraduates enjoy learning the English Language through social media as they are exposed to many benefits. They also believe that social media have the means to empower both the instructors as well as the undergraduates in sharing educational information. It can be inferred that continuous exposure to the English Language in social media helps undergraduates improve the competence in the language and communication skills. Besides that, the educators also can suggest and provide constructive feedback or bring in new and useful educational information on social media. The educators' positive feedback towards students' posts may help and encourage students to be more active in sharing their thoughts and views on social media. While the majority of the respondents agreed to learning vocabulary through social media, some of the respondents did not agree that they could benefit from the online platforms in improving their language competence. However, it can be generalised that social media tools afford undergraduates with multiple benefits to develop and improve their English language vocabulary. This result concurs with previous studies by Akhiar, et al. (2017), Saqib and Khan (2016); Mubarak (2016).

\section{Learning English Vocabulary through Social Media}

Khan (2016) claimed that social media facilitates vocabulary building for the users especially learning new words, phrases and improving their vocabulary. Table 5 shows the functions of social media in learning vocabulary in the English language at the university level. All the respondents opined that social media empowers them to learn new words in the English Language. 98.9\% of the respondents felt that repetitive exposure to the English Language in social media helps them to progress their vocabulary and communication skills respectively. This finding concurs with Annamalai, (2018); Mubarak (2016) who emphasised that social media help to improve learning activities among undergraduates. Furthermore, Mubarak also highlighted that there is a positive attitude towards social media as this platform was perceived by the undergraduates as a beneficial learning medium to improve their second language learning.

When asked if the use of social media is very supportive in English Language vocabulary expansion, $99 \%$ of the respondents agreed to the statement as social media offers more exposure and flexibility in vocabulary learning. As expected, all the undergraduates agreed that they discovered new vocabulary daily through the use of social media while $96.8 \%$ said that learning through social media can be retained in the long-term memory more efficiently. This finding corresponds with Alsamadani, (2018); Li (2017) who advocated that social media is a good platform for language learning to undergraduates as it consists of numerous images and videos for teaching purposes. 
INTERNATIONAL JOURNAL OF ACADEMIC RESEARCH IN PROGRESSIVE EDUCATION AND DEVELOPMENT

Vol. 9, No. 4, 2020, E-ISSN: $2226-6348$ @ 2020 HRMARS

Table 5: Social media in learning vocabulary of English Language at University Level

\begin{tabular}{|l|c|c|}
\hline \multicolumn{1}{|c|}{ Items } & $\begin{array}{c}\text { Agree } \\
\%\end{array}$ & $\begin{array}{c}\text { Disagree } \\
\%\end{array}$ \\
\hline $\begin{array}{l}\text { Social media enables user to learn new words in English } \\
\text { Language }\end{array}$ & 100 & - \\
\hline $\begin{array}{l}\text { Repetitive exposure to the English Language in social media } \\
\text { help students improve their vocabulary }\end{array}$ & 98.9 & 1.1 \\
\hline $\begin{array}{l}\text { Repetitive exposure to the English Language in social media } \\
\text { could help students improve their communication skills. }\end{array}$ & 98.9 & 1.1 \\
\hline $\begin{array}{l}\text { The use of Social Media is very helpful in English Language } \\
\text { vocabulary development. }\end{array}$ & 99.0 & 1.0 \\
\hline $\begin{array}{l}\text { Social media offers more exposure and flexibility in vocabulary } \\
\text { learning } \\
\text { new vocabulary daily }\end{array}$ & 100 & - \\
\hline $\begin{array}{l}\text { I can practice new words and learn new vocabulary through } \\
\text { interaction via social media }\end{array}$ & 100 & -9.9 \\
\hline $\begin{array}{l}\text { Words can be retained in the long-term memory more efficiently } \\
\text { when learn English vocabulary through social media }\end{array}$ & 96.8 & 3.2 \\
\hline $\begin{array}{l}\text { There are more opportunities for vocabulary development using } \\
\text { social media }\end{array}$ & 97.9 & 2.1 \\
\hline $\begin{array}{l}\text { The environment in social media helps its users to learn English } \\
\text { actively }\end{array}$ & & \\
\hline $\begin{array}{l}\text { Social media provides English vocabulary contents which contain } \\
\text { words and images }\end{array}$ & & \\
\hline
\end{tabular}

All the respondents (100\%) also perceived that they acquired new vocabulary through interaction via social media. This is agreed by Arumugam et al. (2019) and Omar (2017) who said that social media motivate users to interact inside and outside the classroom, connect with people all around the world, deliver knowledge of feedback and improve students' academic performance. A total of $97.9 \%$ indicated that there are more opportunities for vocabulary development while using social media. Moreover, $94.6 \%$ of the respondents felt that the dynamic environment in social media helps its users to learn English actively while $95.7 \%$ said learning new vocabulary via social media is interesting because the words are accompanied with images.

This study has clearly demonstrated the evidence that social media did help university students in their English Language vocabulary development. Most of the undergraduates agreed that social media have a lot of functions that help students in improving their English vocabulary. 
Vol. 9, No. 4, 2020, E-ISSN: $2226-6348$ @ 2020 HRMARS

The features on social media enable the users to share educational information and many agreed that new vocabulary can be discovered daily through the use of social media. Education nowadays has emerged with modern technologies to improve learning and social media serve as an important tool in students' learning. According to a previous study by Arumugam et al. (2019 and Mahmud and Ching (2012), social media have positively helped students' attitude in reading and writing expressively, as well as improving their grammatical skills.

Table 6: Correlation between time spent on social media and learning new words

\begin{tabular}{|c|c|c|c|}
\hline & & $\begin{array}{c}\text { Time spent on social } \\
\text { media }\end{array}$ & $\begin{array}{c}\text { Perception on } \\
\text { learning new } \\
\text { vocabulary in the } \\
\text { English }\end{array}$ \\
\hline \multirow[t]{2}{*}{$\begin{array}{l}\text { Time spent on social } \\
\text { media }\end{array}$} & $\begin{array}{l}\text { Correlation } \\
\text { Coefficient }\end{array}$ & 1 & $.327^{*}$ \\
\hline & Sig. (2-tailed) & & 0.021 \\
\hline \multirow{2}{*}{$\begin{array}{l}\text { Perception on } \\
\text { learning new } \\
\text { vocabulary in the } \\
\text { English }\end{array}$} & $\begin{array}{l}\text { Correlation } \\
\text { Coefficient }\end{array}$ & .0 .021 & 1 \\
\hline & Sig. (2-tailed) & 0.021 & \\
\hline
\end{tabular}

Spearmen Correlation was used to find the correlation between time spent on social media and perception toward learning new vocabulary in the English language. Table 6 shows the $p$-value between mean score of student spending time on social media and perception on learning new vocabulary in the English is 0.021 with p-value less than significant level at 0.05. Therefore, it can be concluded that there is a relationship between undergraduates spending time on social media and their perception on learning new vocabulary in English. They believe that the more time they spend on social media, the more they learn new words. The results show that there is a relationship between the usage of social media and competence in the language among undergraduates along with the widespread usage of gadgets. Undergraduates who used social media intelligently developed their language proficiency (Alnjadat et al. 2019; Arumugam et at, 2019).

\section{Conclusion}

On the whole, it can be concluded that students in UiTM have gained from using social media to learn vocabulary. Social media is certainly an apt tool to be used by lecturers to comunicate with students on course-related material. The myriad features on social media allow its users of all age groups to use the applications to share information such as educational information in text and images form. Because of this, many undergraduates agreed that educators should use social media to supplement the traditional teaching and learning methods. Other than that, social media offers many advantages, mobility and accessibility through smartphones making it suitable for continuous language exposure (Alnjadat et al. 2019; Mubarak, 2014). Moreover, social media enables its users to upload picture or video that contextualises visual data which assist in English 
language learning and at the same time, socially encourages users to be connected in a community of online learners. Although a small number of respondents considered learning English vocabulary through traditional-based classroom were boring and insufficient, many strongly believed that traditional teaching approach is still impacts to a certain level. It is noteworthy that social media offers a range of feature that assist undergraduates' communication skills, knowledge and English language proficiency (Ahmadi, 2017; Mubarak, 2016).

\section{Recommendations}

Needless to say, with the development of new technologies, it is important for educators to know the perceptions of university students towards using social media as an interactive learning tool. In order to motivate the students to participate actively in the learning setting, educators may inspire students to use social media more frequently to build a social relationship with nativespeaking students. As second language learners, it is important for undergraduates to learn new vocabularies from different internet tools as they need to use them in writing and speaking. Students are recommended to broaden their reading resources, not only academic books, newspapers or magazines but to make use of the abundant resources available in the virtual learning environment. Even so, students should be reminded to manage and allocate their time wisely for social media to avoid any distractions and negative influences. For future research, it would be more reliable to examine the diverse benefits and challenges in relation to social media for the learners of all levels. Future research should also be broadened to multicultural respondents from other institutions to obtain better insights on social media. Additionally, prospective researchers can analyse the use of social media on other language skills such as reading or writing skills.

\section{Corresponding Author}

Nalini Arumugam

Akademi Pengajian Bahasa Universiti Teknologi MARA, 40150 Shah Alam, Selangor Darul Ehsan

Malaysia

Email: nalini@uitm.edu.my

\section{References}

Abdulahi, A., Samadi, B., \& Gharleghi, B. (2014). A study on the negative effects of social networking sites such as facebook among asia pacific university scholars in Malaysia. International Journal of Business and Social Science, 5(10).

Abrahim, S., Mir, B. A., Suhara, H., \& Sato, M. (2018). Exploring Academic Use of Online Social Networking Sites (SNS) for Language Learning: Japanese Students' Perceptions and Attitudes Towards Facebook. Journal of Information Technology \& Software Engineering. 8: 223. doi: 10.4172/2175-7866.1000223

Ahmadi, M. R. (2017). The impact of motivation on reading comprehension. International Journal of Research in English Education. Retrieved from http://www.ijreeonline.com

Ahmed, M. A. (2016). Using Facebook to Develop Grammar Discussion and Writing Skills in English as a Foreign Language for University Students. US English Teaching. 
Akram, M. S., \& Albalawi, W. (2016). Youths' social media adoption: Theoretical model and empirical evidence. International Journal of Business and Management, 11(2), 22-30. http://dx.doi.org/10.5539/ijbm.v11n2p22

Alnjadat, R., Hmaidi, M. M., Samha, T. E. D., Hijazi, A. M. M., \& Hasswan, A. A. M. (2019). Gender variation in social media usage and academic performance among University of Sharjah students. DOI: 10.1016/j.jtumed.2019.05.002

Alqahtani, M. (2015). The Importance of Vocabulary in Language Learning and How to be taught. International Journal of Teaching and Education, 21- 34.

Alsamadani. 2018). Teachers could use these platforms in order to encourage students or learners to learn or improve their English Language skills in reading and writing, formally and informally

Amichai-Hamburger, Y. (2013). The Social Net: Understanding our Online Behavior $\left(2^{\text {nd }}\right.$ ed.). Oxford: OUP.

Annamalai, N. (2018). Exploring the use of Facebook and other social media sites in preservice teacher education.

Badri, M., AlNuaimi, A., Asma, Y. G., \& AlRashedi. (2017). School performance, social networking effects, and learning of school children: Evidence of reciprocal relationships in Abu Dhabi, Telematics and Informatics, 34 (8), P. 1433-1444.

Balakrishnan, V., \& Lay, G. (2016). Student's learning style and their effects on the use of social media technology for learning. Telematics and Informatics, 33, 808-821.

Bevan, J. L. (2017). Liking, creeping, and password sharing: Romantic jealousy experience and expression and social networking sites. In N. M. Punyanunt-Carter \& J. S. Wrench (Eds.), The impact of social media in modern romantic relationships (pp. 165-181). Lanham, MD, US: Lexington Books

Castells, M. (2007). Mobile communication and society: A Global perspective. Cambridge: The MIT Press

Chawinga, W. D. (2017). Taking social media to a university classroom: teaching and learning using Twitter and blogs. International Journal of Educational Technology in Higher Education, 14(1). doi:10.1186/s41239-017-0041-6

Churchill, D., Wong, W., Law, N., Salter, D., \& Tai, B. (2009). Social bookmarkingrepository-networking: Possibilities for support of teaching and learning in higher education. Serials Review, 35(3), 142-148.

Dhanya, G. (2016). Influence of social media on English language learning. Journal of English Language and Literature (JOELL), 3(1), 105-110.

Davis, F. D. (1989). Perceived Usefulness, Perceived Ease of Use, and User Acceptance of Information Technology, MIS Quarterly, 13(3), 319-339.

Duff, P. A. (2002), The discursive co-construction of knowledge, Identity, and Difference: An Ethnography of Communication in the High School Mainstream. Applied Linguistics 23(3), 289-322.

Faizi, R., El Afia, A., \& Chiheb, R. (2013). Exploring the Potential Benefits of Using Social Media in Education. International Journal of Engineering Pedagogy (iJEP), 3(4), 50. doi:10.3991/ijep.v3i4.2836

García Trejos, S. R., Diaz Pascuas, R. L., \& Artunduaga Cuellar, M. T. (2018). Skype sessions 
INTERNATIONAL JOURNAL OF ACADEMIC RESEARCH IN PROGRESSIVE EDUCATION AND DEVELOPMENT

Vol. 9, No. 4, 2020, E-ISSN: $2226-6348$ @ 2020 HRMARS

as a way to provide additional oral practice of English university students. Colombian Applied Linguistics Journal, 20(1), 62-78.

García-Umaña, A., \& Tirado-Morueta, R. T. (2017). Digital Media Behavior of School Students: Abusive Use of the Internet, Journal New Approaches In Educational Research, $7(2)$, p.140 - 147.

Glenn, D. (2013). Importance of Staying Connected Through Social Media Retrieve from www.business 2 community.com/social-media/importance-staying connect-socialmedia-0600521\#u5sHjIMAQOKKc9WC.9.

Gu, Y. Q. (2003b).Vocabulary learning in a second language; Person, taks, context, and statragies (Electronic version). TESL-EJ, 7, A-4 from http://wwwwriting.berkeley.edu/TESL-EJ/ej26/a4.html

Grosseck, G., Bran, R., \& Tiru, L. (2011). Dear teacher, what should I write on my wall? A study on academic uses of Facebook. Procedia Social and Behavioral Sciences, 15, pp. 1425-1430.

Hafedh, H. S. (2019). Social media impact on language learning for Specific purposes: A study in English for business administration. Teaching English with Technology, 56-71.

Hashim, K. F., Rashid, A., \& Atalla, S. (2018). Social Media for Teaching and Learning within Higher Education Institution: A Bibliometric Analysis of the Literature. International Journal of Interactive Mobile Technologies (iJIM) 12(7):4, DOI: 10.3991/ijim.v12i7.9634

Khan, M. S. (2016). The Role of Social Media in Development of English Langauge Vocabulary at University Level. International Journal of Academic Research in Business and Social Sciences, 590 - 604.

Khan, I. U., Ayaz, M., Iara, M. F. (2016). The Role of Social Media in Development of English Language Vocabulary at University Level, International Journal of Academic Research in Business and Social Sciences, 6 (12). ISSN: 2222-6990

Kitchakarn, O. (2016). How Students Perceived Social Media as a Learning Tool in Enhancing their Language Learning Performance. The Turkish Online Journal of Educational Technology.

Lin, C. H., Warschauer, M., \& Blake, R. (2016). Language learning through social networks. Language Learning and Technology, 20(1), 124-147. Retrieved from https://scholarspace.manoa.hawaii.edu/bitstream/10125/44449/1/20_01_linwarschau erblake.pdf

Li, V. (2017). Social Media in English Language Teaching and Learning. International Journal of Learning and Teaching, 3.

Malerba, M. L. (2011). Social Networking in Second Language Learning

Martin, J. A. (2014). Mobile media and political participation: Defining and developing an emerging field, Computers in Human Behavior 68, P. 269-275. https://doi.org/10.1177/2050157914520847

Mahmud and Ching. (2012). Use of Social Media for Informal Language Learning by Malaysian University Students. 3L: The Southeast Asian Journal of English Language Studies, 25(4): $68-83$.

Mohammed, H. Al-Khazaalia, K. \& Al-Kadhum, I. (2019). An Exploratory Study of Micro 
INTERNATIONAL JOURNAL OF ACADEMIC RESEARCH IN PROGRESSIVE EDUCATION AND

DEVELOPMENT

Vol. 9, No. 4, 2020, E-ISSN: $2226-6348$ @ 2020 HRMARS

Context and Macro-Context Barriers to Teaching English Language in Iraqi EFL High School Framework, International Journal of Innovation, Creativity and Change. 11(3), 13-28. Retrieved from www.ijicc.net.

Mubarak, A. A. (2016). Learning English as a Second Language through Social Media: Saudi Arabian Tertiary Context. International Journal of Linguistics.

Mutum, D., \& Wang, Q. (2010). Consumer Generated Advertising in Blogs. In M Neal (Ed.), Handbook of Research on Digital Media and Advertising: User Generated Content Consumption, 248-261, IGI Global.

Mustapha, L. K., \& Atoloye, S. A. (2019). Influence of satirical media content on orientation to politics among Nigerian youth. SEARCH Journal of Media and Communication Research, 11(2), 2019, 91-110. Retrieved from http://search.taylors.edu.my ISSN: 26727080 | Print ISSN: 2229-872X

Nation, I. S. P. (2001).Learning vocabulary in another language. Cambridge: Cambridge University Press

Nations. (2019) Social media main mode of communication. The Star, p. E18.

Nunan, D. (1991.) Language Teaching Methodology. A Textbook for Teachers. London: Prentice Hall.

Nobari, A. D., Reshadatmand, N., \& Neshati, M. (2017). Analysis of Telegram, An Instant Messaging Service. In CIKM. 2035-2038

O'Keeffe, G. S.-P. (2011). The impact of social media on children, adolescents, and families. Pediatrics, 127, p.800-804.

Omar, F. I. (2017). Gen Y: A study on social media use and outcomes. Journal of Management \& Muamalah 6 (1), P. 53-64.

Oliver L. H., Dame-Griff, A., Capello, E., \& Richter, Z. (2019). Tumblr was a trans technology: the meaning, importance, history, and future of trans technologies. Retrieved from https://doi.org/10.1080/14680777.2019.1678505.

Rivers, W. M. (1989). Communicating Naturally in a Second Language. Theory and Practice in Language Teaching. Cambridge: Cambridge University Press.

Schmitt, N. (2000). Vocabulary in language teaching. Cambridge: Cambridge University Press.

Selwyn, N. (2012). Social Media in Higher Education. The Europa World of Learning. Routledge. www.worldoflearning.com. Retrieved from http://www.educationarena.com/pdf/sample/sample-essay-selwyn.pdf

Tozcu, A., \& Coady, J. (2004). Successful learning of frequent vocabulary through CALL also benefits reading comprehension and speed. Computer Assisted Language Learning, $17(5), 473-495$.

Vermeren, I. (2015). Men vs. women. Who is more active in social media? Brandwatch. Retrieved August 27, 2016 from https://www.brandwatch.com/2015/01/men-vswomen-active-social-media/.

Viera, R. T. (2017). Vocabulary knowledge in the production of written texts: a case study on EFL language learners, Revista Tecnológica ESPOL RTE, 30,(3), 89-105.

Wang, J. L., Jackson, L. A., Gaskin, J. E., \& Wang, H. Z. (2014). The effects of Social 
INTERNATIONAL JOURNAL OF ACADEMIC RESEARCH IN PROGRESSIVE EDUCATION AND DEVELOPMENT

Vol. 9, No. 4, 2020, E-ISSN: 2226-6348 @ 2020 HRMARS

Networking Site (SNS) use on college students' friendship and well-being. Computers in Human Behavior 37, 229-236. DOI: 10.1016/j.chb.2014.04.051

Wu, W.-C. V., Marek, M. W., \& Huang, H. W. (2012). Using Skype and Facebook as social media to enhance learner communicative competence and cultural awareness in an EFL advanced conversation class. Presented in CALL Conference: Taichung, Taiwan.

Yu, A., Tian, S., Vogel, D., \& Kwok, R. (2010). Embedded social learning in online social networking. In ICIS 2010 Proceedings, Saint Louis, Missouri, USA. Retrieved 18 June 2017 from

https://www.researchgate.net/publication/221599873_Embedded_Social_Learning_in_ Online_Social_Network 